\title{
Futebol mulato: racial constructs in Brazilian football
}

\author{
Tiago Fernandes Maranhão \\ Universidade Federal de Pernambuco (PE- Brazil)
}

\author{
Jorge Knijnik \\ University of Western Sydney
}

\begin{abstract}
The aim of this paper is to review Gilberto Freyre's ideas about futebol mulato and the way these ideas have spread the notion of the Brazilian mulatto as a symbol of a 'racial democracy', unique in Brazil, around the world. The notion first appeared in 1938 in an article by Freyre for the Diários Associados, an important Brazilian newspaper. Football (soccer) was employed by Freyre as the special arena where the multiracial Brazilian nation could shine and show the world a different way of being, opposed to the white and 'rational' way of European football. In Freyre's work, the so-called 'football-art' was compared to poetry, while the European style was equated with prose. This essay argues that Freyre's ideas were useful in constructing the Brazilian identity, a nation of harmony in all its aspects, including the area of race, and how the idea of the mulatto has been used to minimise social disparities within Brazilian society. Freyre's ideas remain contemporary; many Brazilian intellectuals still refer to these concepts. As well, the press in this huge country, and especially in World Cup years, uses the concepts of mulatto and football-art to characterize Brazil and differentiate it from other countries.
\end{abstract}

\section{Introduction}

The aim of this paper is to discuss Gilberto Freyre's ideas about Futebol Mulato. Freyre (1900 to1987) was one of the most influential Brazilian social scientists of the twentieth century; his ideas about race have been studied and, indeed, revered, since the first half that century. Freyre also wrote about sport, especially football, and its role in the formation of Brazilian identity.

Modern sport is a territory replete with powerful myths; on a daily basis it creates and recreates heroes and epics stories, building one of the most influential of cultural phenomena in the globalized era (Elias and Dunning 1992). Some sports, and among them football (soccer), have become more than just sport: they shine with their own light and have become, in the course of last century, playful, even religious rituals of enormous proportions, exerting a strong influence in the construction of contemporary national identities. 
The process of constructing a nation is a weaving together of different political, economic and social tendencies using symbols, rituals and practices that unite the population in periodic celebrations expressing community (Hobsbawm and Ranger 1985; Hobsbawm 1990).

Nowadays, football celebrations actively participate in the formation and the reinforcement of this sense of collectivity, of nation, of a 'we' that is located above and beyond individual awareness.

Brazil, one of many nation-states where football is effectively experienced on a religious scale, is a good example of how this sport, itself metaphor of war and struggle for social power, has been transformed into an enormous carrier of signs through which some of the threads that texture the creation of a national psyche can be glimpsed. Football is more than a game in Brazil; it is, as the title of Alex Bellos’ book (2002) states, The Brazilian way of life. Brazilians play football everywhere possible: at school, on beaches, on streets, in slums (favelas) or in traffic, from recreational formats to organized championships, from basic to professional levels which involve high amounts of sponsorship and money. Football is highlighted in all media every single day. The country stops during a FIFA World Cup. Schools, banks and the courts are closed; everybody is watching 'the game'.

In the Brazilian context, the analysis of football celebrations allows a privileged perspective on the process of the construction of the national identity based on a system of 'racial democracy', a process that is often considered a model and even more so now when terms such as multiculturalism, multiracialism and mestization appear with so much force in the speeches of powerful members of society (Anderson, 2005; Caldeira, 2005).

\section{Our Goals}

Does Brazilian football have the mulatto profile Freyre identified? To what extent can it be said to have contributed to the creation of Brazil's culture? How did it develop, historically and socially? Is the mulatto profile a real brand of the nation? 
It is important to state that Freyre's concept of futebol mulato was first highlighted in an article he wrote for a newspaper called Diários Associados in 1938. This article, 'Foot-ball ${ }^{1}$ mulato' is the foundation and one of the most important statements of Freyre's theories about Brazilian football and its mulatto characteristics.

The aim of this paper is to discuss the importance of Freyre's idea and how it has influenced social representations of Brazilian football around the world ${ }^{2}$. Taking Freyre's ideas about race and ethnicity, and his discussion of the nature of the Brazilian mulatto, this paper discusses his ideas which, seven decades later, still reverberate in debate on ethnic and racial issues in Brazilian football.

A recent book by Jose Miguel Wisnik, a significant literary professor, critic and musician who is well-known among Brazilian intellectuals, has reopened the debate about the concepts of the game of football which is played around the world. Briefly, the ideas Wisnik presents in this book (2008), which was published by one of major Brazil's leading commercial book publishers and widely promoted in Brazilian's most important newspapers as well as on Brazilian cultural TV shows, recapitulate Freyre’s main argument from 1938. Wisnik argues that Brazilian football is a kind of poetry while the football played in Europe is more like prose in style. The latter goes straight ahead to the goal, whereas the former likes to adorn and flourish its movements, like a dance between feet and ball. The characteristics highlighted by Wisnik are virtually identical to those Freyre expressed more than 70 years ago. This paper explores Freyre's ideas and racial constructs in Brazilian football at a time of renewed interest in this subject.

\section{A nation of mulattos: football as an icon of mulatism}

The policy of racial segregation in Brazil underwent important changes in the first decades of the twentieth century (Capuchinho 2005). Then, the theory of the 'whitening process', promoted by the aristocracy with its European traditions, was widely diffused. The theory pleaded for the elimination through miscegenation of the Afro (black) and indigenous

\footnotetext{
${ }^{1}$ In the first half of the 20th century, English was the official language of Brazilian football. People used and wrote in English to refer to football terms such as corner, goal, and foot-ball. From the 1960s, Portuguese words and expressions began to replace English terms.

${ }^{2}$ Despite the fact that when talking about Brazilian football most of people would think about men's football, it is important to recognize that women have continuously played football in that country since the 1940s, or even earlier (Knijnik 2011).
} 
components in a process of nation construction that would copy Europe, the model of culture and progress, a refined and rational region.

The black and indigenous minorities were portrayed as damaging the cohesion of social identity and retarding economic development. In particular, the blacks and the mulattos, the latter identified by mixed-ethnicities or more commonly by a range of dark skin tones, liberated from their conditions of slaves in 1888, were considered by the elites to be insolent, loquacious and imaginative, ready only for celebration, diversion and luxury and with neither the persistence needed for work or the capacity to learn anything to do with work (Schwarcz 1999).

All 'non-white' cultural manifestations were systematically disqualified as symbols of the evil, belonging to a malignant and essentially sensual primitive world that did not have the capacity to be Europeanized. The rites of candomblé (religion), capoeira (martial arts and dance) and samba (music and dance), all of African origin, were totally prohibited and severely repressed in the public sphere (Maciel 1999).

This scenario changed with the irruption of the nationalistic, centralized and antimonarchical ideologies that characterized the bourgeoisie in a transatlantic trend. The 'nationalistic revolution’ of 1930 led by by Getulio Vargas, ${ }^{3}$ aiming to industrialize, modernize and promote reconciliation between groups within the country, devised new economic and social strategies destined to promote a common idea of Brazil that would bridge the stark differences which existed in all aspects of social life. In fewer than thirty years, some of the 'not-white' manifestations, previously ridiculed and despised, were transformed into national symbols, reasons for pride and preservationist fervour for the ‘Brazilian people’ (Capuchinho 1999).

From that time, Brazilian identity, (from a cultural perspective found in books and movies highlighting black protagonists and heroes), began to be constructed on the basis of a series of symbolic interchanges in which one of the main protagonists was the black-mulatto of African origin. In a very short time, the figure of the black African-Brazilian moved from one

\footnotetext{
${ }^{3}$ Getulio Vargas (1882-1954), after being the leader of the 1930 Revolution which put an end in the 'Old Republic', was twice the Brazilian President: the first time for 15 years, from 1930 to 1945, and the second time, from 1951 to 1954, when he killed himself.
} 
continually subject to humiliation, that is slavery, persecution, torture and social marginalization, to one occupying a radically different position in the folklore and the popular culture of the nation. And the playful-festive manifestations such as the samba, carnaval and football, constituted the privileged space in which that transformation took place (Schwarcz 1999).

The symbolic figure of the mulatto, as well as being a mediator in the conflicting social relations between the different cultural and racial spheres, is directly related to the social meaning of football, the activity through which the 'Brazilian being' expresses itself with greatest intensity.

Gradually, the mulatto started to be considered as a creator and symbol of brazilianism, the pride of Brazilians. The social sciences actively participated in this 'racially mixed' irruption. It was through them that the theoretical basis was designed, serving to create a positive concept of African-Brazilians and vindicating them as the pivot of a new social model destined to equip the nation with 'brazilianism'. In this context, the theories of the anthropologist Gilberto Freyre about mestiçagem (miscegenation, racial mixing) could be considered as forming one of the most solid of the foundation pillars on which the construction of the new Brazilian national identity was built. His innovative perspective rejected the idea of the superiority of the 'white’ race (Maciel 1999).

Freyre's perspective was clearly and publicly demonstrated in the insightful 'Foot-ball mulato’ article of 1938. At that time, the Diários Associados was a leading and influential Brazilian newspaper; in the article, Freyre maintained that the football played in Brazil was a kind of dance, where the human being could shine, as opposed to the football played in Europe which, he thought, was overly mechanized.

By arguing that the mulatismo of Brazilian football would represent the real psychological character of the Brazilian people ${ }^{4}$ - 'being a Brazilian is being a mulatto' - Freyre was also laying the grounds for the strongly-held sociological concept that is now common thinking about this profound and remarkable cultural manifestation in Brazil - football.

\footnotetext{
${ }^{4}$ Juliana Cabral, the captain and leader of the Brazilian women's football team that took the silver medal in the 2004 Olympics, reinforces the point that women should be included when talking about this 'psychological character of the Brazilian people' and football. In a testimony quoted in Knijnik (2011) she said that 'And I think many people think that soccer is just for men. But I don’t think so!(...) Women’s soccer is about technical quality, about swing’.
} 


\section{Gilberto Freyre and the racially mixed Brazilian}

According to Freyre's theory, Brazil was and would always be 'racially mixed' and that ‘original mestization' should not only feed the national psyche but also must be, simultaneously, a source of pride and vindication of its special identity. In earlier times, seen as degenerative and the cause of great common evils, mestization now appeared to be interpreted as a positive process for Brazilians as they invent a new tradition, their own identity. In his major and best known book, Casa Grande \& Senzala, ${ }^{5}$ Freyre emphasised the importance of both the slave owners - whites who lived in big houses, the Casa grande - and the slaves - mostly African blacks who lived in the Senzala, which were housing areas with miserable conditions - in the construction of Brazilian identity. It was, of course, the relationships between these two groups, socially and notably sexually, which produced the mulatto descendents. According to Freyre, this process was benign and formed the basis of Brazilian 'racial democracy'. Freyre’s article is a search for (in quest of the preservation of) the 'authenticity of the Brazilian folk', rejecting European notions and emphasising the importance of transforming ludic elements through which individual members of society revealed their passionate natures more openly. He can be seen as the founder of the 'racially mixed ideology' underpinning the 'Brazilian way of being' and football was a key site in the evolution of brasilidade (Brazilian-ness).

After football began to take on a truly international dimension, Freyre collaborated as a contributor to newspapers and magazines, continuing to fervently advocate the advantages of the mulatto style of playing football. This mulatto football would be an indispensable condition for the creation of 'our [Brazilians'] own style' of playing football, shaping a distinct mode, constructed in a game of opposition in respect to 'the European playing style'. Nevertheless, the choice of the black / mulatto as a distinguishing symbol, among many other possibilities available, points to the fact that Brazilian popular culture was hugely influenced by the slaves who came from Africa during the previous centuries. ${ }^{6}$ Freyre argued for the recognition of these influences, replacing the denial of the elites who preferred to be connected to and build Brazilian culture as a mimesis of European culture.

\footnotetext{
${ }^{5}$ Casagrande \& Senzala was first published in 1933, and was published in English as The Masters and the Slaves. Freyre published 17 books and numerous articles and was the recipient of 25 national and international awards, such as the Anisfield-Wolf (US, 1957), Grand Cross of Dom Afonso The Wise (Spain, 1983) and The (Brazilian) National Library Medal (1984).

${ }^{6}$ 1559-1888. The Portuguese Crown officially sanctioned the capture of and traffic in black slaves in 1559; slavery was abolished in 1888.
} 


\section{Poetry, football-art and the mulatto - a distinctive Brazilian case}

The intense, lively participation of European modernist artists in the 'discovery of the black' during the two first decades of the 1900s had its affect on the development of Brazilian national identity. The sudden interest in the African world among an important part of the French intelligentsia directly affected the African-Brazilian situation, in which black culture had been despised, an invisible part of the artistic world until that time.

In the Europe of 1920s, 'negrophilia' was a key part of a period of huge cultural change; it was created by the irruption on the European scene of a number of evocative black figures in the world of music (jazz) and sport (boxers), for example. Entertainment and spectacle were the doors through which black culture was introduced into the halls of the elites (Harris 1995).

In the dynamic stage of the construction of a 'racially mixed character' as a defining characteristic of Brazilian nationality, the integration, the spectacularization and sportivization of the dances and rites ${ }^{7}$ related to black-mulatto bodies had a crucial role. The social spaces opened up to the most underprivileged members of society and, in theory, destabilizing those spaces, were all related to festive rituals and spectacular performance, especially music and sport, the two main sites of the mediation which Freyre's 'racial democracy’ celebrates.

Currently, a generalized feeling is perceived in the world of football that associates the practice of football in Brazil, and the passion this sport arouses among Brazilians, to natural or innate features. This image of Brazilian football can be observed, from other countries (Helal, Lovisolo and Soares 2001). The ability of Brazilian football players is seen as a gift in the blood, a racial mark that, simultaneously, characterizes the players and distinguishes them from the other human beings. The very 'nature' of the Brazilian people is to play football, and Brazil reveals its collective face to the world during international competitions.

Brazilians think they have a natural gift to play football because football mulatto was born in Brazil: this is the powerful myth that Freyre helped to propagate ${ }^{8}$.

\footnotetext{
${ }^{7}$ Since those days, racists have insulted black people by calling them 'monkeys', saying that they dance and play like monkeys. It is possible even now to see these insults when the Brazilian Team goes to play in Argentina: the most important Argentinean sports newspaper frequently prints as its headlines 'The monkeys are coming!'

${ }^{8}$ Juliana Cabral thinks women have this natural gift as well: 'So, I think a woman's place is in soccer! I think it is a sport that identifies with a woman' (quoted in Knijnik, 2011).
} 
Hylton (2009, p.2) asserts that, especially in sport, human capacities are always naturalized from the physical and psychological characteristics of each person or social group. The author asserts that it is from a belief in the existence of these characteristics that people try to predict who will succeed or fail in the sports arena. With this in mind, and naming numerous athletes whose conduct, inside and outside the sports field, contests racial stereotypes such as 'Asians make good footballers' or 'excellent white basketball players', or even 'good black athletes who speak well for the press', Hylton believes, paradoxically, that 'the racialised social structures of sport therefore contribute to the way we shape and experience our own and others' identities' (2009, p.2).

The nationwide identification with the Brazilian National Team of Footballers, known as 'The Selection', whose performances paralyze the country and whose victories generate massive and troubled celebrations, serves to assist the evocation of a 'united Brazilian nation', under the same colours, the same idols and the same slogans. And the phrase 'paralyze the country' means just that: everything stops, including banks, schools and courts; a 'national holiday' is given so that everyone can see 'The Selection' play 'the match'.

In his constructional definitions relating to the way football is played in Brazil, Freyre prioritized a number of categories he formulated on the basis of racial characteristics associated with 'mestization' (the racial mixing). In the intervening seventy years, the most notable 'form of being' of Brazilian football is described as 'football-art', a term widely used in the media, which 'valorises' black / mulattos bodies as its main creators. This category of art, applied to Brazilian football, began to take strength when the idea was transformed into part of the way Brazil projected itself on a global scale. With the successive triumphs at the World Cups in 1958, 1962 and 1970, Brazilian football began to be described as 'a wonderful work of art' created out of 'mestization' and the active participation of the black and mulatto players.

The construction of the 'mulatto' category was deeply linked to the search for a form, aesthetically different and 'authentic', that would reveal the Brazilian ethos. In this sense, football, among many other things the dramatization of a combat between bodies appeared as a perfect field in which the 'true Brazilian body' could finally see 'the light'. 
The history of Brazilian football has been considered by many writers as the conflict of 'football art' with 'football force' behind which, almost always, is sublimated another weighty system of oppositions: the 'irrationality' of Brazilian society versus the 'rationality' that supposedly characterizes Europe and the Occident in general.

For theoreticians of Brazilian football, the ideal game is a sort of 'danced football' that necessarily must include the possibility for elastic improvisation by the mulattos. In his 1938 paper, Freyre argues that

our mulatto football, with the artistic floridness whose efficiency - less in defense than in attack - was demonstrated with brilliance during the matches held this year against the Polish and the Czechoslovakians, is an expression of our social formation, democratic like nothing else and rebellious to excesses of internal and external ordering; to excesses of all that is uniform, geometrical and standardized; to radicalisms which make individual variation or personal spontaneity disappear (1938, p.4).

Brazilian mulatismo has become known for its taste for flexibility and for surprise and floridness which recall dancing and capoeira steps, particularly its dance elements. It is a dance which allows improvisation, diversity and individual spontaneity. It is a lyrical kind of dance. All these years' later writers are saying essentially the same thing as Freyre said in 1938. In the last decade of the $20^{\text {th }}$ Century, there were still writers stating almost the same ideas: 'While European football is an Apollonian expression of a scientific method and socialist sport in which personal action is mechanized and subordinated to the whole, the Brazilian is a sort of dance, in which the person is prominent and shines' (Coutinho 1994, pp. 53-60).

Freyre's desire to establish a clear distinction between 'the European' and 'the Brazilian', based on a nationalistic strategy, was intended to present a unique and distinctive way of playing football which related to a social structure that was rebellious to excesses of internal and external organization and rebellious to excesses of uniformization and totalitarianisms that militate against individual variation and spontaneity. The orthodox 'Apollonian' game originating in England has become, according to Freyre, in the symbology of Brazilian football, 'a Dionysian' dance. It could also be viewed as a space for resistance, as Lefebvre (1991) conceptualizes it: a space where Brazilians can resist European influence and be themselves. The fact that Brazilians play football everywhere, not just on recognised sports 
fields, could be seen as a way of resisting foreign influences and of promoting their native mulatto culture.

European football, based on values such as objectivity, strength, speed and resistance, would be played according to scientific methods of physical and technical training. The most important unwritten rule would be that the team must follow the tactics of the game, developed beforehand on theory, with sobriety and effectiveness. Tactical and athletic discipline constitutes the supreme values. The players must be united and restless, hard to individualize (Freyre 1938). Football-art, on the other hand, is represented in a very different way. According to Freyre (1938), the 'instinctive' and 'natural' qualities of ability, touch, spontaneity and malice are attributed to the Brazilian player. The capacity for improvisation and the importance of individual talent produces a 'beautiful' football, a sport of exhibition.

As Roberto da Matta maintains, the division that emerges between the concepts of 'footballart' and 'strength-football' directly relates to the resistance between 'Western European rationality' and a society such as Brazil which articulates itself to a large extent on the relation between the magical and supernatural world:

Strength-football expresses a style where the emphasis in rational training is more intense. Football-art talks about charisma, luck, malandragem (trickery), game-of-waist, beauty and a carnival-like seduction. On the one hand there is the western idea of exercise as the basis of everything; on the other hand the idea repressed by the liberal and bourgeois capitalist West, of an enchanted world where the Gods exist and speak with men (da Matta 1995, p.15).

This game of oppositions is also transferred to the world of the fans, the other great protagonists in the football celebrations of Brazil. In this way, the self-perception the supporters have about how they cheer is closely connected with the aspects (mentioned above) that oppose western rationality against the supposedly 'irrational essence’ of Brazilian society. Against the enthusiastic, the musical and dancing fans from Brazil there would be the static, cold and critical fans from Europe. ${ }^{9}$

\section{Futebol mulato: Freyre's ideas and football players in Brazil}

World Cup years are invariably special years for Brazil. The FIFA World Cup 2010 in South Africa was even more special for Brazilians for its being the first to be staged in Africa, a

\footnotetext{
${ }^{9}$ It is worthwhile to remark that this image would not be accurate considering the violence and damage provoked by Europeans fans mainly in the 1980s and 90s (Murphy, Willians and Dunning 1990).
} 
continent with which Brazil has a significant cultural identification, particularly because of the creation of the mulatto with its specifically African origins.

Nevertheless, even nowadays, some opinion makers 'implicitly believe in a whiter Brazil, even if it were no longer respectable to talk about it, living with an intellectual legacy from their parents and grandparents and their commitment in relation to racist theories' (Skidmore 1993, p. 239). The issue of race is still widely present in Brazilian society and receives a great deal of attention from all segments of society. Within this perspective, such content could be a part of sports and become highly functional in the political process of imagining the community. By being such a cornerstone of Brazilian cultural identity, and to a great extent the product of a political and cultural project headed by the Government and the national political classes, football merits consideration in its historical and cultural context and for its role in the creation of Brazilian identity.

It is for this reason that it is useful to reflect on Freyre's discourse on Brazilian football and his racial analysis of the game. Figueiroa notes that there are, for example, a number of ideas that are constantly repeated: 'the trickster (malandro) style of the Brazilian player, with skill' and 'the ballet-like football, of Afro-Brazilian dance with dribbles' (Figueiroa 2003, p. 3). These expressions strongly reflect ideas rooted in the collective national imagination, to the extent that it seems these concepts have always existed, making it impossible to raise any objection to them as 'facts'. When talking about the 'history of the black in football', one could say that this history is told by 'another person' (Freyre in this case) and this means that the discourse either determines the place from whence the black should speak or gives them no voice' (Orlandi 1990, p. 50).

However, between 1900 and 1930, there was a social movement marking the first fight from a "minority" group (which is the majority in the Brazilian historical evolution). This black protest was embodied and flourished in the 1930s, spreading just beyond the subsequent decade. It was suffocated by the difficult conditions under which black people lived and the intolerance of the Estado Novo in confronting what was in effect "structurally democratic" (Fernandes 1989).

In this context, the model of 'imagining the Brazilian nation' proposed by Freyre seeks to solve the problem of integration of immigrants and Afro-Brazilians: to inculcate the feeling 
of being part of the nation in these people. The image of mulatto superiority over the 'rigid' Europeans, proposed by Freyre, found its expression in the Dionysius versus Apollo opposition, where the mestizo (mulatto) would represent the smart tropical style, a skilful and ludic one which could surpass the hard and disciplined European mode. Football provided a powerful way to stimulate a feeling of 'belonging' for the Brazilian population; it also spread Freyre's ideas regarding the full-fledged, triumphant and, consequently, superior nation of mulattos. This thinking conveyed a nationalist agenda and became highly functional in the process of imagining the community. Using football as evidence that in Brazil 'superior race and a superior society’ was being developed, Freyre created and imagined a new avenue for the social integration of the black/mulatto in Brazilian society - the mulatto football as the symbol of the 'racial democracy' (Maranhão 2006). The implication here is that the use of this symbolism was deliberately used by political forces to ensure that the power of the elite remained intact.

When describing people, Freyre excludes the possibility whereby People X could have the characteristics of People Y. In other words, he does not explicitly claim that Brazilians are undisciplined and disorderly. However, he makes such a claim by implication when he describes Europeans as behaving in the opposite manner. Europeans would have a rational game due to their 'organization', while Brazilians would have a 'distinct' way of playing, representing the disorganization of the country and its Afro-Brazilian culture. In summary, the unspoken qualities related to 'rationality', 'calculus' and 'order' in Brazilian football reflect the same idea with regards to the structure of society.

There is, however, the so-called 'silent discourse' in Freyre's works. In other words, there are passages where 'it is necessary to say nothing in order to be able to say something' (Orlandi 1950, p. 52). An example of this is when Brazilian players (that is, Brazilian people) are said to have a way of playing that is 'unmistakably, exclusively ours' and the European style is 'calculated, ordered, mathematical, Apollonian and British' (Freyre 1974, p.6). Brazilians are not seen as a disciplined and orderly people. Further, when it is claimed that 'they [Africans and Afro-descendants] are the ones who tend to reduce everything to dancing - work or play' (Freyre 2001, p. 182), they cannot be considered 'serious' or 'rational'.

According Freyre, the Brazilian players, mainly the mulattos, have introduced the art of playing football, they have developed the beauty and the lightness of dancing with the ball; 
'we dance with the ball', Freyre exclaims. No process of identity construction is able to be sustained without the presence of 'idols', 'stars' or 'heroes' who represent the outstanding members the community, those who seem to exceed the limits of the human condition. Many mulatto players, in the 1930s were gradually gaining the status of 'idols', players like Leônidas (the Black Diamant) ${ }^{10}$, Didi, Domingos da Guia among many others - in a process which the pinnacle was Pelé ${ }^{11}$ in the end of the 1950s (Filho 1964).

In Brazil, the popularization and massive diffusion of football practices were carried out through the constructions of mulatto idols. It was an abrupt turn that took the 'not-white ones' from the being despised to being considered heroes, representatives of the Brazilian-ness. Brazilians know that they are worldwide recognized as a land of 'samba and futebol', which means black/mulatto bodies expressing spectacular performances while dancing and playing. The construction of the Brazilian nationality is well connected to the black/mulatto bodies. Remembering Freyre: 'Psychologically, being a Brazilian is being mulatto'

The Brazilian political system, during the process of national construction after the 'revolution' leaded by Vargas ( in 1930), focussed on generating visible spaces, movements and illusional relationships between potentially dangerous sections of society, certainly to serve its interests but, simultaneously, to ensure that the power of the political-economicintellectual elite remained intact. In the centre of this process was 'mestization', now seen as constituting the symbolic foundation of the nation and appearing as the point of mediation between different disparate groups and elevated to an ideology of pacification and resolution of conflict. The mulatto has been used to smooth the interracial conflicts in an extremely polarized society. From this perspective, the mulatto works much more as a stereotype to be simultaneously exported and for internal pacification. ${ }^{12}$

\footnotetext{
${ }^{10}$ Leônidas da Silva was a celebrated black Brazilian player during the 1930s and 40s. The nickname 'Black Diamant' was also the name of a chocolate bar which was introduced at the time to celebrate Leônidas and it is still popular today. Leônidas was the creator of the bicycle kick, one of the great juggling gestures in football, where the player literally flies with no feet on the ground and back to the goal while kicking the ball over his head.

${ }^{11}$ Pele, 'the athlete of the 20th century', was known as a 'black with a white soul' in conservative sectors of Brazilian society. Football in Brazil was first played in the beginning of the $20^{\text {th }}$ Century only by the elites in high-society - white clubs and it was forbidden to blacks / mulattos, some of whom, such as Arthur Friedenreich, used white powder (makeup) and straightened their hair to look white (Filho 1964).

${ }^{12}$ Florestan Fernandes (1989), one of the most world-renewed Brazilian social scientists, charged in 1951 to make a study of blacks in Brazil to UNESCO, has researched the relationship between race and class in Sao Paulo. On that occasion, he threw himself to the confrontation of the idea that in Brazil there was a "racial democracy", supported by Gilberto Freyre. It was one of the first times that Freyre's ideas were confronted by social scientists. After that, in the 1970s, 'Brazil's black movement would reject this idea ('racial democracy') as a 'myth' that occluded widespread discrimination' (Alberto 2008, p. 81).
} 
At first sight, one might think that Freyre's discourse on the black and the mulatto seems to be flattering, that somehow, he sought the perfect Brazilian or the eugenic mulatto. In 1976, Freyre wrote a note for the second edition ${ }^{13}$ of the book 'Ingleses no Brasil' (The English in Brazil). It is worth reproducing an excerpt about the changes of football players in Brazil:

... at first, anglicized Brazilians and the natives with some Britishness in looks and behavior (...); after, increasingly, the different degrees of the dark-skinned until the deanglicization culminating in the amazing Pelé, after having shone in Leônidas. It is curious that the process described is the opposite of the proposed eugenic theory of 'whitening' (Freyre 1977, p. 15).

Thus, the aim and the product of miscegenation should be the darkening of the white both culturally and spiritually ${ }^{14}$. Football, thus, would be the explicit representation of the perfect performance of an ideal 'race'. In World Cup seasons that discourse always returns with power.

This affirmation derives from the fact that football is, in fact, an event involving the emotions, engaging the whole human being and is indeed part of the construction of the national spirit. Evaluation is more plausible during large-scale events such as the World Cup, whether for acts of heroism, or for failure and subsequent disappointment. As it is a national issue, when the Brazilian National Team does not achieve the 'deserved result' in important competitions, there is a tendency to look for those who should be blamed and often the style that was used unsuccessfully is questioned. On many occasions, the playing style is criticized for not being 'the true Brazilian style'.

After the elimination of the Brazilian team in 1990 World Cup, when it was defeated by Argentina, the so-called 'Dunga Age' was fiercely criticized. Dunga played for Brazil in 1990 and was the image of the 'European style'. The Brazilian press reacted this way:

The attempt to organize Brazilian football failed, leaving the natural talent and improvising skills, in favour of a more rigid standard of defensive play, that of the European style. Brazil

\footnotetext{
${ }^{13}$ The second edition is dated 1977.

${ }^{14}$ Even if this process of darkness smoothly occurred in the Brazilian society, with a very slow integration of black people within the society, nowadays black/mulatto are still at the bottom of the social pyramid, they are the majority of the poor people. Positives agendas and inclusive policies are in place in some spheres of the Brazilian society (such as the public higher education sector) in order to compensate hundreds of years of black oppression.
} 
was eliminated (...) The 'Dunga Age' hasn't come (...) The advantage of the defeat is the necessity to re-evaluate those concepts of tough football. ${ }^{15}$

Some social groups, in such a context, use images that are available in the cultural sphere and re-use them (originally or not) to qualify magnanimities and frustrations. Hence, all discussion about football in Brazil carries an evaluative meaning, a conducer of traces of discrimination, judgment, distinction, prejudice and taboo.

It is no exaggeration to say that Freyre's texts inaugurated a tradition of cultural studies in Social Sciences in the field of football. It is clear that his thinking has influenced the writing of the history of sport in Brazilian by writers such as Mario Filho and Nelson Rodrigues, both of whom were friends of Freyre. This tradition continues to the present day in the work of authors such as Roberto Da Matta, José Sergio Leite Lopes, Simoni Guedes, Antônio Jorge Soares, José Miguel Wisnik and others who, adopting or responding to Freyre’s ideas, are engaged in a dialogue with his work on 'Foot-ball mulatto'. This indicates how important and perennial this theme is.

On deeper reflection, it may be possible to reveal what is meant by the term 'Brazilian' through Freyre's discourse on football. His concept of what is to be Brazilian created an idea of Brazilian-ness which remained in the intellectual and popular representations throughout the twentieth century, and remains so in the twenty-first century.

Brazil failed again in the South Africa FIFA World Cup in 2010. The Brazilian team's coach in South Africa was Dunga, the player who was the symbol of the 'anti-Brazilian style' during the 1990s. Brazilian fans and press, and indeed the world of football (fans, press, and commentators around the world) complained that the team was not playing 'like Brazilians'. In all the criticism ran the thread of Freyre: everybody expects that Brazilians should play in the mulatto style. His ideas about being Brazilian remain with us, influencing the new century.

\section{Acknowledgements}

The authors would like to acknowledge Dr Bob Petersen ('Gentleman Bruiser') and Mr. Brett Johnson for the substantial comments and insights they made during the preparation of this essay.

\footnotetext{
${ }^{15}$ O Dia newspaper, 25 June 1990, p.3. Four years later, in 1994 at the end of the US World Cup, Brazil was the champion, and Dunga, as the National team's captain, raised the cup. Before and after him, every National team's captain had kissed the cup, as a gesture of love. He was the only captain among the five world cups that Brazil won who, instead of kissing the Cup, has blamed everybody, yelling against his 'detractors', the ones he hated: the Brazilian press and journalists.
} 


\section{References}

Alberto, P. 2008, 'Para africano ver: African-Bahian Exchanges in the Reinvention of Brazil's Racial Democracy, 1961-63’. Luso-Brazilian Review, vol.45, no.1, pp.78-117.

Anderson, B. 2005, Comunidades Imaginadas, Edições 70, Lisboa.

Bellos, A. 2002, Futebol, the Brazilian way of life, Bloomsbury, London.

Caldeira, J. 2005, 'Uma Nação Global', Retrieved on 11 July 2005 from the Ministry of Foreign Affairs:

http://www.mre.gov.br/cdbrasil/itamaraty/web/port/consnac/nacglob/apresent/apresent.htm

Capuchinho, C. 2005, 'Brasil vive ilusão da democracia racial', Retrieved on 19 April 2005 from http://noticias.usp.br/canalacontece/artigo.php?id=3066

Coutinho, E. 1994, Gilberto Freyre, Agir, Rio de Janeiro.

Da Matta, R. 1995, 'Brasil: futebol tetracampeão do mundo' - Pesquisa de campo, n. 1. UERJ, Rio de Janeiro.

Elias, N. \& Dunning, E. 1992, Deporte y ocio en el proceso de la civilización. Fondo de la Cultura Económica, Madrid.

Fernandes, F. 1989, O Significado do Protesto Negro, Cortez Editora, São Paulo.

Filho, M. 1964, O Negro no Futebol Brasileiro, Civilização Brasileira, Rio de Janeiro.

Figueiroa, F. 2003, 'A Invenção do Futebol-Arte', Diário de Pernambuco, 07 September 2003, p.3.

Freyre, G. 1938, 'Foot-ball mulato', Diários Associados, 17 June 1938, p.4.

Freyre, G. 1946, The Masters and the Slaves, a study in the development of Brazilian civilization, Alfred A. Knopf, New York.

Freyre, G. 1974, 'Futebol desbrasileirado?’ Diário de Pernambuco, 30 June 1974, p.6.

Freyre, G., 1977, Ingleses no Brasil, Livraria Jose Olympio, Rio de Janeiro.

Freyre, G. 2001, Interpretação do Brasil; Aspectos da formação social brasileira como processo de amalgamento de raças e culturas, Companhia das Letras, São Paulo.

Harris, M. 1995, Culture, people, nature, An introduction to general anthropology, Harper Collins College Publishers, New York.

Helal, R. , Lovisolo, H. \& Soares, A.J.2001, A invenção do país do futebol - Mídia, Raça e Idolatria, Manuad, Rio de Janeiro.

Hylton, K. 2009, 'Race' and Sport: Critical Race Theory. Routledge, Oxford.

Hobsbawm, E. 1990, Nation and Nationalism since 1780; Programme, myth, reality. Cambridge University Press, Cambridge.

Hobsbawm, E. \& Ranger, T. 1985, The invention of tradition, Cambridge University Press, Cambridge.

Knijnik, J. 2011, 'From the Cradle to Athens: The Silver-Coated Story of a Warrior in Brazilian Soccer',Sporting Traditions, vol. 28, no.1, pp. 63-83.

Knijnik, J. and Vasconcellos, E. 2005, 'Les femmes en crampons à coeur ouvert au Brésil'. In: Sport et genre: v1 - La conquête d'une citadelle masculine, ed. Thierry Terret. L' Harmattan, Paris, pp. 295-308.

Lefebvre, H. 1991, The Production of Space. Blackwell, Malden, MA.

Maciel, M. E. 1999, 'A Eugenia no Brasil', Revista Anos 90, no.11, São Paulo, Perspectiva, $4^{\text {th }}$ edition.

Maranhão, T. F., 2006. 'Apolineos e dionisiacos' - o papel do futebol no pensamento de Gilberto Freyre a respeito do 'povo brasileiro', Analise Social, no.179, pp. 435-50.

Murphy, P. , Williams, J. \& Dunning, E. 1990, Football on Trial - Spectator Violence and Development in the Football World. Routledge, London. 
Orlandi, E. P. 1990, Terra à Vista. Discurso do confronto: velho e novo mundo, Cortez Editora, São Paulo.

Rialto, Jorge (Gilberto Freyre), 1929, 'Fair Play', A Província, 19 December 1929, p. 3.

Schwarcz, L.M. 1999, The Spectacle of the Races; Scientists, Institutions and the Race Question in Brazil, 1870-1930, Hill and Wang, New York.

Skidmore, T. S. 1993, Black into White: Race and Nationality in Brazilian Thought, Duke University Press, London.

Wisnik, J. M. 2008, Veneno Remédio - o futebol e o Brasil, Companhia das Letras, São Paulo. 